www.mdpi.com/journal/humanities

Article

\title{
Rorty, Pragmatism, and Analytic Philosophy
}

\section{Cheryl Misak}

Department of Philosophy, University of Toronto, 170 St. George Street, Toronto, M5R 2M8, Canada; E-Mail: cheryl.misak@utoronto.ca

Received: 12 June 2013; in revised form: 28 June 2013 / Accepted: 9 July 2013 /

Published: 10 July 2013

\begin{abstract}
One of Richard Rorty's legacies is to have put a Jamesian version of pragmatism on the contemporary philosophical map. Part of his argument has been that pragmatism and analytic philosophy are set against each other, with pragmatism almost having been killed off by the reigning analytic philosophy. The argument of this paper is that there is a better and more interesting reading of both the history of pragmatism and the history of analytic philosophy.
\end{abstract}

Keywords: William James; analytic philosophy; history of pragmatism; Peirce; logical Empiricism

\section{Introduction}

A complaint has run through pragmatism for the last few decades. That complaint is that analytic philosophy has nearly killed off pragmatism. On this view, which Robert Talisse ${ }^{1}$ has called the 'eclipse view', when Richard Rorty brought his considerable talents to the pragmatist scene in the 1970s, there were very few pragmatists or students of American philosophy in top-tier American universities. Pragmatism was operating on the margins, driven from philosophy departments by the reigning analytic philosophy. Rorty resurrected it from its near-death, but in a resolutely anti-analytic version, a version despised by the ruling philosophical class. ${ }^{2}$ The idea is that pragmatism is set against analytic philosophy and has suffered from challenging this wrong-headed but domineering winner of the philosophical stakes. A sense of persecution has thus hung over certain quarters of American pragmatism. Rorty himself has promoted the view:

\footnotetext{
Talisse is as set against it as I am.

2 See ([1], p. 1) for an example of this view.
} 
Along about 1945, American philosophers were, for better or worse, bored with Dewey, and thus with pragmatism. They were sick of being told that pragmatism was the philosophy of American democracy, that Dewey was the great American intellectual figure of their century, and the like. They wanted something new, something they could get their philosophical teeth into. What showed up, thanks to Hitler and various other historical contingencies, was logical empiricism, an early version of what we now call 'analytic philosophy' ([2], p. 70).

While the young Rorty worked within the analytic mode, by 1970 his uneasiness with analytic philosophy was emerging ([3], p. 18). He felt that it had become the mainstream and was flooding out other genres of philosophy, including the history of philosophy. The 1960s had seen the emergence of a movement of "pluralists"-philosophers who wanted to see more diversity in the kinds of papers presented at the American Philosophical Association meetings and the kind of appointments made in top departments. In 1979, Rorty was president of the Eastern APA and had to deal with an unprecedented alternative nomination for his successor from the floor. The pluralists had packed the business meeting and nominated John Smith, a Yale scholar of American pragmatism and one of Rorty's old teachers. There were questions about the legitimacy of the maneuver and about procedural irregularities. In the end, Rorty declared the election valid and became very publically identified with the challenge to the dominance of mainstream methods. The episode made the New York Times.

When Rorty left his faculty position at Princeton in 1982, it was in large part because he was disillusioned with professional philosophy. He left for an interdisciplinary position as Professor of Humanities at the University of Virginia and then went to Stanford in 1998 to be Professor of Comparative Literature. Many of Rorty's followers still believe that to have been his student or to work on pragmatist topics is to put oneself at risk failure in the academic job market. In the preface to his volume in the Library of Living Philosophers, which Rorty saw to completion in the final days of his life, Randy Auxier says: "Rorty prudently exiled himself from professional philosophy so as not to damage the careers of those who wanted to study with him” ([4], p. xxix).

In The American Pragmatists [5], I argue that Rorty's view is a misreading of both the history of pragmatism and the history of analytic philosophy. Insofar as the distinction between analytic and non-analytic philosophy retains any force, the founders of pragmatism were pioneers of analytic philosophy. The alternative history I give is rooted very securely in the work of the founders of pragmatism, especially Chauncey Wright and C. S. Peirce, and its tendrils reach into the work of every one of the classical pragmatists and into contemporary philosophy. I will offer a highly condensed version of that argument here. It is by necessity the barest sketch and the interested reader should turn to The American Pragmatists for the requisite detail and nuance.

\section{Two Versions of Pragmatism}

Pragmatism was founded in the late 1860s by C.S. Peirce, William James, and Chauncey Wright. The central insight of pragmatism is that we must start from where we find ourselves - as human beings, laden with beliefs and practices, trying to make sense of ourselves and our world. As Peirce put it, we must not adopt empty metaphysical theories — we must stay away from "vagabond thoughts that tramp the public roads without any human habitation". Rather, we must "begin with men and their conversation” ([6], p. 112). This insight, shared by all the founders of pragmatism and their successors, 
results in a naturalist (as opposed to supernaturalist) view, put nicely by the un-justly neglected Chauncey Wright. He rails against the "a priori school” of philosophy, aligning himself with the "positive mode of thought", which investigates the world by observation, experiment, and verification ([7], p. 44).

When the pragmatist applies these principles to the concept of truth, a set of anti-metaphysical questions immediately arise. How could anyone aim for a truth that goes beyond experience or beyond the best that inquiry could do? How could an inquirer adopt a methodology that might achieve that aim? The very idea of the believer-independent world, and the items within it to which beliefs might correspond or represent, seems graspable only if we could somehow step outside of our practices. The correspondence theory, Peirce says, makes truth "a useless word" and "having no use for this meaning of the word "truth", we had better use the word in another sense" ([8], p. 553).

Peirce is perfectly happy with the correspondence theory as a 'nominal' definition, good only to those who have never encountered the concept before ([6], p. 100). He is intent on preserving the important idea that truth is something objective-not a matter of what we might happen or choose to believe. But we need to illuminate this basic idea of truth by considering its linkages with inquiry, assertion, belief and action. For those are the human 'dealings' relevant to truth ([8], p. 416).

All this is shared pragmatist principle. But forks soon appear in the path. In 'The Fixation of Belief' Peirce's delivers his view of how the concept of truth arises from our practices. He is very careful to give us an argument that does not beg the question-that does not presuppose a particular concept of truth while trying to excavate that very concept from our practices of inquiry. He is resolute about starting with the idea that in inquiry, what we want is to settle our belief, so that we have something on which to act. His argument is that not just any old settled belief will do-it is not so easy to settle belief. ${ }^{3}$ He tells us that the a priori method, for instance, is a 'failure', for it

makes of inquiry something similar to the development of taste; but taste, unfortunately, is always more or less a matter of fashion ... [And] I cannot help seeing that ... sentiments in their development will be very greatly determined by accidental causes. Now, there are some people, among whom I must suppose that my reader is to be found, who, when they see that any belief of theirs is determined by any circumstance extraneous to the facts, will from that moment not merely admit in words that that belief is doubtful, but will experience a real doubt of it, so that it ceases to be a belief ([10], p. 253, emphasis added).

Beliefs resign in the face of recalcitrant experience or in the knowledge that they were put in place by a method that did not take experience seriously.

That is, when Peirce suggests that true beliefs are those on which there would be agreement at the end of inquiry, he requires that the agreement be warranted by how things are, whatever that amounts to in this or that domain of inquiry. When we ask how truth is linked to our practices, we find that a true belief is one that would be 'indefeasible'; or would not be improved upon; or would never lead to disappointment; or would forever meet the challenges of reasons, argument, and evidence. A true belief is the belief we would come to, were we to inquire as far as we could on a matter.

3 See [9] for a sustained reading of 'The Fixation of Belief' and for the argument that Peirce is concerned to not presuppose the notion of truth. 
Peirce was also clear that the 'we' in question had to be seen as encompassing everyone. Since individuals have finite lives, "logicality inexorably requires that our interests shall not be limited. They must not stop at our own fate, but must embrace the whole community” ([10], p. 284). Truth is not a matter for individuals. Logic is rooted in a 'social principle,' for investigation into what is true is not a private interest but an interest "as wide as the community can turn out to be” ([8], p. 357).

Peirce was a difficult man and one of the great intellectual tragedies of philosophy is that he was drummed out of the academy because of that and on the heels of what was then considered a scandalous divorce and quick re-marriage. William James was, on the other hand, America's most famous and most respected academic. It was thus James who was the face of pragmatism, not the almost-unheard-of Peirce.

James sparred with Peirce and Wright over the pragmatist account of truth, promoting a view on which the community in question could be as small as an individual. Although he sometimes articulated a view very much like Peirce’s (such as in 'The Moral Philosopher and Moral Life'), he more often than not put forward a radical view on which truth varied from person to person and from time to time. In his most contentious articulation, he argued that if one needs to believe something, then one ought to believe it, even if there is no evidence in its favor. Beliefs are true for an individual: “Any idea upon which we can ride ... any idea that will carry us prosperously from any one part of our experience to any other part, linking things satisfactorily, working securely, simplifying, saving labor, is ... true instrumentally" ([11], p. 34). "Satisfactorily”, for James, "means more satisfactorily to ourselves, and individuals will emphasize their points of satisfaction differently. To a certain degree, therefore, everything here is plastic” ([11], p. 35).

This radical view came under serious bombardment. Here is Bertrand Russell on James:

We must suppose that ... the consequences of entertaining the belief are better than those of rejecting it. In order to know this, we must know what are the consequences of entertaining it, and what are the consequences of rejecting it; we must know also what consequences are good, what bad, what consequences are better, and what worse ([12], p. 201).

This, of course, is a very tall order, which Russell immediately illustrates. The consequences of believing the doctrine of the Catholic faith might make one happy "at the expense of a certain amount of stupidity and priestly domination” ([12], p. 201) but it is entirely unclear how we are to weigh these benefits and burdens against each other. The effects of Rousseau's doctrines had far-reaching effects on Europe, but how do we disentangle what the effects have been? Even if we could do that, whether we take them to be good or bad depends on our political views.

Russell points out that one can take 'works' or 'pays' in two very different ways. In science, a hypothesis works if we can deduce a number of verifiable hypotheses from it. But for James, a hypothesis works if "the effects of believing it are good, including among the effects . . the emotions entailed by it or its perceived consequences, and the actions to which we are prompted by it or its perceived consequences". As Russell goes on to note, “This is a totally different conception of 'working', and one for which the authority of scientific procedure cannot be invoked” ([12], p. 210).

G.E. Moore also interrogates the linkage between the true and the useful. If usefulness is a property that may come and go, then "a belief, which occurs at several different times, may be true at some of the times at which it occurs, and yet untrue at others” ([13], p. 183). The truth of a belief, that is, will 
vary from time to time and from culture to culture. Moore thinks that the idea that truth is not a stable property of beliefs is an anathema.

James's view came under similar stress in America. Peirce was but one who objected: "I thought your Will to Believe was a very exaggerated utterance, such as injures a serious man very much...” [14]. He says that James' view is: “Oh, I could not believe so-and-so, because I should be wretched if I did" ([8], p. 377).

Nonetheless, when John Dewey took over the reins of pragmatism, he succeeded James in being America's most famous and respected academic. Pragmatism, that is, continued to dominate American philosophy.

\section{Pragmatism and Logical Empiricism}

The eclipse view has it that pragmatism and logical empiricism did battle, with pragmatism quickly finding itself on the bullied end. But this is not, I shall argue, an accurate account of the engagement between logical empiricism and pragmatism. When the logical empiricists arrived in America, they found a soil in which their position could thrive. They did not arrive in a land that was inhospitable to their view, nor did they need to uproot the view they found already planted there.

Logical empiricism came into being in the mid-1920s when a group of philosophers, physicists, mathematicians, social scientists, and economists in Vienna gathered around Moritz Schlick and another group in Berlin gathered around Hans Reichenbach. Hitler and the impending Second World War did indeed scatter this talent, much of it to America. The logical empiricists ignited excitement in American philosophy departments. Their positions were crisp and clear; their knowledge of logic and science was unassailable; they were driven by a sense of purpose and a mission to clean up the metaphysical squalor in which they thought philosophy lived; and they thought that progress is possible only if all inquiry is scientific.

The logical empiricists aimed to unify all inquiry under the umbrella of science. Neurath started, edited, and nurtured The International Encyclopedia of Unified Science and this, teamed with a set of influential conferences, was for a long time the official forum for logical empiricism-its "organized contemporary expression” ([15], p. 2). The unification of inquiry was to proceed with a new and important resource - the formal or symbolic logic that was developed in the latter part of the nineteenth century by Frege. Peirce was also a pioneer, developing a first order quantified logic independently of but at the same time as Frege. It was also to proceed along the lines of the verifiability principle, which was a stronger notion than the verification of the pragmatists-all meaningful sentences were to be reducible, via deductive logic, to statements that are empirically verifiable. Thus, no meaningful question is in principle unanswerable by science and the statements of metaphysics, ethics, and religion are cast into suspicion.

It is important to remember that pragmatism from the beginning thought of itself as being in the spirit of positivism. Arthur Lovejoy remarks on it in 1909, speaking of James. Pragmatism, he says, is "a modern expression" of the positivism of Comte and others, reducing meaning and truth to the pointing to particulars in concrete experience ([16], p. 577). Lovejoy is not quite right. Pragmatism did not and does not seek to reduce meaning and truth to the pointing to particulars-Peirce, at least, was very clear that he was talking about an aspect of meaningfulness, not the whole of it. But Lovejoy is 
right that Peirce, Wright, and James argued that if you try to divorce philosophical concepts from experience and practice, you lose contact with what is real and you sink into useless metaphysics.

The similarity between Peirce and the logical empiricists was noticed by the logical empiricists. Neurath, in the first volume of the Encyclopedia, says the following in setting out the history of logical empiricism:

The connection between modern logic and empiricism did not arise instantly... A few of the modern logicians, such as Peirce, and, later on, Bertrand Russell, combined the interest in logic with an interest in empiricism. Traditional idealistic philosophers did not discuss carefully or look with favor upon this new combination of logicalization and empiricalization. The fact that Peirce was a logician and simultaneously interested in empiricism was in turn important for the preparation of modern scientific empiricism in the United States ([15], p. 17).

This introductory volume of the Encyclopedia-Volume 1, Number 1-has the connection between pragmatism and logical empiricism as a theme running throughout it.

Peirce was also the subject of a talk at the fifth International Conference for the Unity of Science, which Charles Morris organized at Harvard in 1940. This was the first of the conferences held in the United States. Ernest Nagel gave a masterful paper titled "Charles S. Peirce: Pioneer of Modern Empiricism". He pointed out the affinities between logical empiricism and pragmatism: the antipathy to metaphysical speculation, the emphasis on cooperative scientific research, and the fact that the pragmatic maxim "was offered to philosophers in order to bring to an end disputes which no observation of facts could settle because they involved terms with no definite meaning” ([17], p. 73). Nagel, as Andrew Jewett [18], argues, tried to convince all parties that logical empiricism and American pragmatism were made for each other.

Of course, Dewey was the pragmatist who reigned when the logical empiricists came to America. And Dewey, more than any other classical pragmatist, had an aim identical to that of the unity of science strain of logical empiricism: to unify all inquiry-physics, ethics, aesthetics, etc. via the experimental method. Russell saw Dewey’s pragmatism as marked by a "very genuine scientific temper”, in contrast to "the will to believers” ([19], p. 147).

Charles Morris (who was part of Dewey's Chicago School), Sidney Hook, Ernest Nagel, and Otto Neurath persuaded Dewey to join forces with the logical empiricists. Dewey was at first reluctant. But he was won over, although perhaps only to Neurath, who he considered the most pragmatist of the logical empiricists (see [20]). He agreed to be on the Encyclopedia's Advisory Committee and he wrote a section of the introductory first volume, alongside Neurath, Carnap, Russell, Morris, and Niels Bohr. His section is titled "Unity of Science as a Social Problem" and in it he is happy to stand with the founders and mainstays of logical empiricism against the "numerous and organized" "enemies of the scientific attitude” ([21], p. 274). He tells us that the scientific attitude can be manifested in every walk of life, for the scientific attitude is the attitude that is freedom from dogma, unexamined tradition, and self-interest. It is a commitment to inquiry, the gathering of evidence, and the drawing of conclusions based only on evidence: "It is the intention to reach beliefs, and to test those that are entertained, on the basis of observed fact” ([21], p. 273). He then tells us that science deals with actual problems and that "The home, the school, the shop, the bedside and hospital, present such problems as truly as does the laboratory.” In 1939 Dewey was the sole author of a volume of the Encyclopedia. 
This volume was titled Theory of Valuation and in it he brings values under the scope of science. He tries to show how propositions about what is good or right are "empirically grounded propositions about desires and interests” ([21], p. 242). Inquiry into values produces verifiable conclusions: we can verify "what individuals and groups hold dear or prize and the grounds upon which they prize them” ([21], p. 243). "Valuation-phenomena,” Dewey argues, "have their immediate source in biological modes of behavior" and "owe their concrete content to the influence of cultural conditions” ([21], p. 249). All of this can be studied.

It is not surprising that some of the attacks on Dewey were identical to those on the logical empiricists. The reaction to Dewey's 1929 The Quest for Certainty, for instance, was that he was too enamored of science. It was said that he illicitly applied science to questions of value. Indeed, reviews of the 1908 Ethics had already seen Dewey as contributing to positivism (see [22,23]; [24], p. 636).

It is pretty clear that Dewey was not out of step with the ideas of the new philosophy. He was, however, out of step with formal logic. While Peirce was a brilliant logician, Dewey had very little interest or ability in it. He hated (and dropped) Peirce's logic class as a graduate student at John's Hopkins during Peirce's fleeting stint as a teacher.

Nonetheless, the new analytic philosophy moved closer and closer to pragmatism as the verifiability principle came under sustained pressure and scrutiny, Neurath put his view of truth and knowledge in terms of a classical metaphor. It was to become a famous image:

There is no way to establish fully secured, neat protocol statements as starting points of the sciences. There is no tabula rasa. We are like sailors who have to rebuild their ship on the open sea, without ever being able to dismantle it in dry-dock and reconstruct it from its best components [25].

This metaphor delivers precisely the same message as Peirce's central metaphor: inquirers are walking on a bog, saying only "this ground seems to hold for the present. Here I will stay till it begins to give way” ([8], p. 589). This is the thought at the heart of pragmatism. Knowledge is fallible and we make revisions when the force of experience causes a particular belief or theory to be thrown into doubt.

Hans Hahn is also happy to throw his lot in with the pragmatists: "As against the metaphysical view that truth consists in an agreement with reality - though this agreement cannot be established-we advocate the pragmatic view that the truth of a statement consists in its confirmation” [26]. Carnap writes in the Library of Living Philosophers volume dedicated to him: "since I came to America, my philosophical views have clearly been influenced by pragmatist ideas” ([27], pp. 860-61). He says that as a result of these pragmatist influences, he puts more emphasis on the social factor in knowledge and on the idea that a "conceptual system” involves practical decisions ([27], p. 861). As George Reisch puts it, there was a "golden age" in which the logical empiricists and the pragmatists were engaged in a collaborative project [28].

\section{The Next Generation of Analytic Pragmatists: Lewis, Goodman, Sellars, Quine}

Charles Morris was right in 1937 to state that the theory of truth held by the logical empiricists "has become very similar to the position of Dewey and Lewis” [29]. C. I. Lewis, indeed, is a vital missing and disrupting piece in the eclipse view. He really puts paid to the idea that pragmatism withered away because it was never fully entrenched in the new professionalized philosophy departments.

Lewis was an undergraduate and graduate student at Harvard, studying with Royce and James: 
In my third and final year, I took the famous course in metaphysics which James and Royce divided between them ... It was immense ... I should be glad to think that the "conceptual pragmatism" of Mind and the World-Order had its roots in that same ground; indeed the general tenor of my own philosophic thinking may have taken shape under the influence of that course ([30], p. 5).

Lewis returned to Harvard in 1920. He "practically lived with" the "manuscript remains” of Peirce for two years. This massive bulk of papers had been left to Harvard in a state of disarray by Peirce's widow and there was some hope that Lewis would start to put them into order ([30], p. 16). He dipped in and out of the Peirce papers for those two years, coming to the opinion that the "originality and wealth" of this "legendary figure" was not fully evident in Peirce's meager published writings and not well represented by those who were influenced by him (James and Royce) ([31], p. 78). It is very clear that he studied these papers closely. His writing teems with Peirce's language and thoughts.

Lewis taught (and influenced) the next generation of first-rank philosophers. The following of his students absorbed his view (not without first trying to distance themselves from their stern teacher) and made pragmatism the dominant philosophy: Quine, Goodman, Sellars. There is not space here to show how these three great pragmatists took their view directly from Lewis (and then how Quine, especially, attacked him). I will confine myself to Sellars, since Rorty says that he spent most of his career extending Sellars' (his own teacher’s) view ([3], p. 8).

Sellars fits beautifully into the pragmatist tradition, yet he was wary of those pragmatists who "misconceive" their important insights about meaning and truth as analyses of meaning and truth ([32], p. 40). Sellars, I have argued, was like Peirce in that he was alert to the possibility that the pragmatist need not define, for instance, truth as successful prediction in the long run ([5]; [33], p. 29).

In 1950, before the appearance of the famous essay "Empiricism and the Philosophy of Mind", Sellars contributed to Sidney Hook's ninetieth-birthday symposium on and for Dewey. His paper is titled "Language, Rules and Behavior" and in it he foreshadows what was to be his major contribution to philosophy - a naturalist/pragmatist position with a coherent and deep account of the normative notions of validity or correctness. In this paper, Sellars tells us that pragmatism has often been characterized as a crude descriptivism on which "all meaningful concepts and problems belong to the empirical or descriptive sciences”. He is gesturing at Dewey when he says that the pragmatist sometimes offers those descriptivist interpretations of truth and moral obligation "with all the fervor of a Dutch boy defending the fertile lands of Naturalism against a threatening rationalistic flood” ([34], pp. 291-92). But pragmatism can be more sophisticated than that ([34], pp. 289-90). He wants to take the pragmatist's insights and offer something less fervent and more rationalist. He wants to come to a naturalist position that makes sense of the normative.

His aim is to explore our evaluative practices - the way we justify something we have done and the way we assess an action as right or wrong, an argument as valid or invalid, a belief as well-grounded or ill-grounded. This exploration is to be conducted, he says, by looking at "some typical contexts in which the terms 'valid' and 'correct' appear to be properly, shall I say correctly, employed” ([34], p. 293). We know how to apply normative terms in our language. It is a skill that one can be better or worse at, just as the one can be better or worse at applying the rules of bridge. He thus calls for a "pragmatic empiricism” ([34], p. 301) that will enlighten us about what it is to follow a rule and be justified in doing so. 
Sellars sees that he will have to make sense of the idea of really getting something right in the face of the fact that the rules of language, science, and logics can change:

Why one set of rules rather than another? How is the adoption of a set of rules itself to be justified? I should like to be able to say that one justifies the adoption of rules pragmatically, and, indeed, this would be at least a first approximation to the truth. The kinship of my views with the more sophisticated forms of pragmatism is obvious ([34], pp. 314-15).

He ends on "a note of caution", expressing with Wittgenstein the view that we cannot get to the very bottom of our rules. The "real connections" or the necessities are merely "shadows" of our rules and not able to be seen in a straight-on way. We operate in a framework of "living rules" and we cannot grasp them or their justification by somehow stepping outside of that framework to get a more objective view on them.

Sellars went on, to great acclaim, to develop these pragmatist ideas. He turns his back on the metaphor of foundations for knowledge:

Above all, the picture is misleading because of its static character. One seems forced to choose between the picture of an elephant which rests on a tortoise (What supports the tortoise?) and the picture of a great Hegelian serpent of knowledge with its tails in its mouth (Where does it begin?). Neither will do. For empirical knowledge, like its sophisticated extension, science, is rational, not because it has a foundation but because it is a self-correcting enterprise which can put any claim in jeopardy, though not all at once ([35], p. 79).

Sellars mounts a sustained and fatal attack on what he calls the "myth of the given"-that "observation 'strictly and properly so-called' is constituted by certain self-authenticating non-verbal episodes, the authority of which is transmitted to verbal and quasi-verbal performances” ([35], p. 77). The Myth is the very strong idea, straight out of the early logical empiricist's book, that "epistemic facts can be analyzed without remainder ... into non-epistemic facts, whether phenomenal or behavioral, public or private" ([35], p. 19).

Sellars argues that there are no basic or pure kinds of knowledge—a belief can only be justified by another belief. Moreover, all beliefs have an inescapably conceptual element. To grasp even something as simple as a triangle requires the concept of triangle so that one can classify it as such. To become aware of something in the first place is to respond to it by applying a concept. Awareness—all of it"is a linguistic affair" ([35], p. 63). One can only be said to have a belief if one is able to locate that belief within the "logical space of reasons". The very meaning of a sentence and the very act of knowing, for Sellars, is its function or role within the game of asking for and accepting reasons_of “justifying and being able to justify what one says” ([35], p. 76). Because knowledge and understanding are conceptual and inferential, they are open to error. This was a point made very clearly by Peirce in 1868 and with the same clarity by Lewis. Sellars goes on to argue that these practices are fundamentally normative: to have possession of a concept means that one is able to employ it correctly so that one can give or withhold reasons for applying it. The ability to use language lies at the heart of human life and normativity lies at the heart of using language.

While it might seem that the practices of giving and asking for reasons are radically subjective, Sellars in fact wants to defend scientific realism against an empiricism that sees human beings as being stuck within the realm of observation, never having knowledge of the external world. He says: 
If I reject the framework of traditional empiricism, it is not because I want to say that empirical knowledge has no foundation. For to put it this way is to suggest that it is really "empirical knowledge so-called", and to put it in a box with rumors and hoaxes. There is clearly some point to the picture of human knowledge as resting on a level of propositions-observation reports—which do not rest on other propositions in the same way as other propositions rest on them ([35], p. 78).

Like Lewis and Peirce, Sellars wants to take experience seriously without making it something mythical-something it cannot be. It cannot be pristine or free of our concepts, but that does not mean that it is not ground knowledge.

For Sellars, truth is correct semantic assertibility. Correct semantic assertibility will look different in different kinds of inquiry-scientific, moral and mathematical. He says: "for a proposition to be true is for it to be assertible, where this means not capable of being asserted (which it must be to be a proposition at all) but correctly assertible...” ([36], p. 101). Sellars, that is, adopts something very much like the pragmatist account of truth.

Again with Peirce, Sellars wants to stay away from the suggestion that the current theories of science are true:

the perspective of the philosopher cannot be limited to that which is methodologically wise for developing science. He must also attempt to envisage the world as pictured from that point of view - one hesitates to call it Completed Science—which is the regulative ideal of the scientific enterprise ([37], pp. 77-78).

On the pragmatism of Peirce, Lewis, and Sellars, we start with what we have and then, with the help of the shock of recalcitrant experience, we reinforce, criticize, and revise where appropriate, until we have a belief that really stands up to evidence and arguments-a belief that would continue to be assertible. This was a dominant view, not just in pragmatist circles, but in the top philosophy departments in America, when Rorty came on the scene.

\section{Rorty’s Revolutionary Pragmatism}

Although Rorty takes much of his inspiration from Dewey, it is tempting to think of him as contemporary pragmatism's William James. Paul Carus said that James's Pragmatism appeared in 1907, “cometlike on our intellectual horizon” [38]. Rorty's Philosophy and the Mirror of Nature appeared, also cometlike, in 1979, reviving the fortunes of Jamesian pragmatism. His narratives, Rorty says, “tend to center around James's version (or, at least, certain selected versions out of the many that James casually tossed off) of the pragmatic theory of truth” ([2], p. 71). Moreover, Rorty, like James, often puts forward a moderate pragmatist view, but it is his less moderate, contentious remarks that have stuck in the minds of philosophers. Peirce howled with outrage that his pragmatism had fallen into "literary clutches" ([8], p. 414). He could see how James's provocative statements were going to damage the more carefully expressed position they shared. I venture he would say the same about Rorty.

Rorty argues that pragmatism, as a movement, contains "ambiguities" that have made it "seem a very muddled movement indeed-neither hard enough for the positivist nor soft enough for the aesthetes” ([39], p. 64). It became “crushed” between these positions after Dewey’s death, and Rorty takes it as his job to extricate it. Though he lauds the efforts of Sidney Hook to keep Deweyan philosophy alive, it is telling that he finds Hook's appeal to scientific method mistaken-too close to 
Quine. As Rorty brings his preferred version of pragmatism into the spotlight, those who hold science in high esteem recede into the background. In his view, it is not clear "why natural science, rather than the arts, or politics, or religion, should take over the area left vacant” by philosophy ([40], p. 171). But while this complaint about Quinean holism may be bang on (it leaves no room for inquiry apart from science and logic), Lewis, Goodman, and Sellars (and Morton White) were putting forward analytic pragmatist positions that did not privilege science.

Rorty was fighting not just against analytic philosophy, but against philosophy in general. In his view, philosophy cannot answer important age-old questions. What it does is dissolve philosophical problems. Philosophy is merely a kind of "therapy". It is more like poetry than science. Philosophy must replace the idea of knowledge with the idea of hope and in doing so the value of philosophy is reduced almost to a vanishing point.

Rorty's Presidential Address at that contentious APA was titled "Pragmatism, Relativism and Irrationalism”. In it, he calls on philosophers to revisit Dewey and James. He notes that the pragmatists were acknowledged by analytic philosophers for having made "various holistic corrections of the atomistic doctrines of the early logical empiricists" ([41], p. 160). But he argues that what was really going on in Dewey and James is a wholesale rejection of the aims of analytic philosophy, not an attempt at making it better. Philosophy must abandon not just the quest for certainty (something every pragmatist wants to abandon), but the very ideas of truth and objectivity. Rorty reconnects Dewey's linkage of pragmatism with culture and politics and tries to unhook pragmatism from epistemology.

Rorty's brand of pragmatism acknowledges that Quine, Sellars, and Davidson ought to be seen as pragmatists ([40], p. 7). But he wants to extend those lines of thought away from what he takes to be analytic philosophy. He wants to take Quine's holism and Sellars's attack on the given in James's direction: "I argue that when extended in a certain way they let us see truth as, in James' phrase, 'what is better for us to believe,' rather than as 'the accurate representation of reality'” ([40], p. 10). His interpretation of Sellars, for instance, has Sellars arguing that "knowledge is inseparable from a social practice - the practice of justifying one’s assertions to one's fellow-humans” ([35], p. 4). But Rorty is even more radical than James. The difference between Rorty and all his pragmatist predecessors is that Rorty thinks that his predecessors focus too much on experience. "Experience," he thinks, is a term we should give up. We should replace it with "discourse". We should "Forget, for the moment, about the external world, as well as about that dubious interface between self and world called 'perceptual

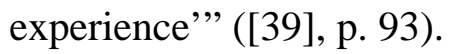

Like all pragmatists, Rorty argues that our concept of truth cannot outrun our practices: "there is nothing deep down inside us except what we have put there ourselves, no criterion that we have not created in the course of creating a practice, no standard of rationality that is not an appeal to such a criterion, no rigorous argumentation that is not obedience to our own conventions” ([41], p. xlii). We must cease thinking of the mind as a great mirror that reflects and represents the world and turn, rather, to our practices to get leverage on our concept of truth. I have argued elsewhere that where Rorty goes wrong is in not taking seriously enough what those practices in fact include (see [5,42]).

When Rorty looks at the practices of first-order inquiry or our current and ongoing "conversations" in which we must form our beliefs, make our decisions, and live our lives, he finds that the notions of truth and objectivity are irrelevant. If one takes the ideas of truth and objectivity in their strongest senses, Rorty is still in line with every other pragmatist. Yearning for an "impossible, indefinable, 
sublime” thing comes at the price of "irrelevance to practice” ([3], p. 2). Inquirers simply cannot aim at that sort of truth and objectivity.

But Rorty then takes a step beyond all other pragmatists. Inquirers aim not at truth, but at solidarity or what we have come to take as true. In his most extreme moods, he asserts that "truth" and "objectivity” are merely labels for what our peers will let us get away with saying ([40], p. 176). He would like to see a "post-philosophical culture" in which there are no appeals to authority of any kind, including appeals to truth and rationality ([41], p. xlii; [2], p. 71). Truth is "not the sort of thing one should expect to have an interesting philosophical theory about" ([41], p. xiii). We are to "substitute the idea of 'unforced agreement' for that of 'objectivity' ” in every domain of inquiry—science as well as morals and politics ([39], pp. 36-38).

The position adopted by Peirce and Lewis is that when we examine our practices, we find the following. We want to settle belief, but it is not so easy to really settle belief. If a belief is determined by "circumstances extraneous to the facts", doubt will be triggered. We will not be satisfied by beliefs that are produced by a method that does not take experience seriously. As Jeffrey Stout puts the point today: "getting something right . . . turns out to be among the human interests that need to be taken into account in an acceptably anthropocentric conception of inquiry as a social practice” ([43], p. 18). The norms of truth and rightness are interwoven throughout our practices of assertion, belief, and inquiry.

\section{Conclusions}

Whatever the path pragmatism takes from this point onward, one thing is clear. The epistemology and the view of truth that dominated analytic philosophy from the 1930s logical empiricism right through to the reign of Quine, Goodman, and Sellars in the 1950s-60s was in fact pragmatism. The stars of modern analytic philosophy were very much in step with pragmatism during the years in which it was supposedly driven out of philosophy departments by analytic philosophers. It was Rorty who broke with the direction the pragmatist tradition was taking and returned to James, even further radicalizing James's view. Pragmatism, that is, had a strong and unbroken analytic history until Rorty came along and cast aspersion on that kind of pragmatism.

The very categories of analytic philosophy versus some contrasting mode, over the last decades, have been disintegrating. In Russell's day, "analysis” had a precise meaning. One term was to be reduced by another set of terms, rendered clear without residue. In Sellars’s memorable words, the big are made small. That characterization of analytic philosophy had already started to dim by the time Rorty was writing. It is no longer clear just what is meant by the term-perhaps it now simply means a rigorous way of thinking about philosophical problems. In that case, we all should be analytic philosophers, whether we are pragmatists or not.

\section{Conflict of Interest}

The author declares no conflict of interest. 


\section{References and Notes}

1. Morris Dickstein, ed. "Introduction: Pragmatism Then and Now.” In The Revival of Pragmatism. Durham: Duke University Press, 1998.

2. Richard Rorty. "Response to Richard Bernstein.” In Rorty and Pragmatism: The Philosopher Responds to His Critics. Edited by H. J. Saakamp. Nashville: Vanderbilt University Press, 1995, 68-71.

3. Richard Rorty. "Intellectual Autobiography.” In The Philosophy of Richard Rorty. Edited by R. Auxier, and L. Hahn. Chicago: Open Court, 2010, 1-24.

4. Randall Auxier. "Preface.” In The Philosophy of Richard Rorty. Edited by R. Auxier, and L. Hahn. Chicago: Open Court, 2010, xvii-xxxi.

5. Cheryl Misak. The American Pragmatists. Oxford: Oxford University Press, 2013.

6. Charles Sanders Peirce. Collected Papers of Charles Sanders Peirce. Edited by A. Burks. Cambridge: Belknap Press, 1931-1958, vol. 8.

7. Chauncey Wright. “The Philosophy of Herbert Spencer.” In Philosophical Discussions. Edited by Charles Eliot Norton. New York: Burt Franklin, 1971.

8. Charles Sanders Peirce. Collected Papers of Charles Sanders Peirce. Edited by C. Hartshorne, and P. Weiss. Cambridge: Belknap Press, 1931-1958, vol. 5.

9. Cheryl Misak. Truth and the End of Inquiry: A Peircean Account of Truth, 2nd ed. Oxford: Oxford University Press, 2004.

10. Charles Sanders Peirce. The Writings of Charles S. Peirce: A Chronological Edition. Edited by E. Moore. Bloomington: Indiana University Press, 1986, vol. 3.

11. William James. Pragmatism: A New Name for some Old Ways of Thinking, The Works of William James. Edited by F.H. Burkhard, F. Bowers, and I.K. Skrupskelis. Cambridge: Harvard University Press, 1975, vol. 1.

12. Bertrand Russell. "William James's Conception of Truth.” In William James: Pragmatism in Focus. Edited by Doris Olin. London: Routledge, 1992, 196-211.

13. G.E. Moore. “Professor James’s “Pragmatism”.” In William James: Pragmatism in Focus. Edited by Doris Olin. London: Routledge, 1992, 161-95.

14. William James. The Correspondence of William James. Edited by I.K. Skrupskelis, and E.M. Berkeley. Charlottesville: University Press of Virginia, 1992-2004, vol. 12, 171.

15. Otto Neurath. "Unified Science as Encyclopedic Integration.” In International Encyclopedia of Unified Science, i/1: Encyclopedia and Unified Science. Edited by Otto Neurath, Rudolph Carnap, and Charles Morris. Chicago: University of Chicago Press, 1938, 1-27.

16. Arthur Lovejoy. "Pragmatism and Realism." The Journal of Philosophy, Psychology and Scientific Methods 6 (1909): 575-80.

17. Ernest Nagel. “Charles S. Peirce: Pioneer of Modern Empiricism.” Philosophy of Science 7 (1940): 69-80.

18. Andrew Jewett. "Canonizing Dewey: Columbia Naturalism, Logical Empiricism, and the Idea of American Philosophy.” Modern Intellectual History 8 (2011): 91-125. 
19. Bertrand Russell. "Professor Dewey's Essays in Experimental Logic.” In The Collected Papers of Bertrand Russell, vol. viii: The Philosophy of Logical Atomism and Other Essays, 1914-19. London: Routledge, 1983, 132-56.

20. Corliss Lamont. Dialogue on John Dewey [by] James T. Farrell [and others]. New York: Horizon Press, 1959, 13.

21. John Dewey. International Encyclopedia of Unified Science, ii/4: Theory of Valuation. Chicago: University of Chicago Press. Reprinted in The Later Works of John Dewey 1925-1953. Edited by Jo Ann Boydston. Carbondale: Southern Illinois University Press, 1939, vol. 13.

22. Kenneth Burke. "Intelligence as a Good.” The New Republic 64 (1930): 77-9.

23. Julius Seelye Bixler. "Professor Dewey Discusses Religion.” Harvard Theological Review 23 (1930): 213-33.

24. Norman Wilde. "Review of Dewy and Tufts, Ethics.” Journal of Philosophy, Psychology, and Scientific Methods 5 (1908): 636-39.

25. Otto Neurath. "Sociology in the Framework of Physicalism.” In Philosophical Papers 1913-1946. Edited by R.S. Cohen, and M. Neurath. Dordrecht: Reidel, 1983, 92.

26. Hans Hahn. Logik, Mathematik, Naturerkennen. Vienna: Gerold, 1987, 43.

27. Rudolph Carnap. "Replies and Systematic Expositions.” In The Philosophy of Rudolph Carnap. Edited by Paul Arthur Schlipp. La Salle: Open Court, 1963, 859-1016.

28. George A. Reisch. A History of the International Encyclopedia of Unified Science. Unpublished Ph.D Dissertation, University of Chicago, 1995, 23.

29. Charles Morris. Logical Positivism, Pragmatism, and Scientific Empiricism. Paris: Hermann, 1937, 4.

30. Clarence Irving Lewis. “Autobiography.” In The Philosophy of C.I. Lewis. Edited by Paul Arthur Schlipp. La Salle: Open Court, 1968, 1-21.

31. Clarence Irving Lewis. "Pragmatism and Current Thought.” In Collected Papers. Edited by John D. Goheen, and John L. Mothershead, Jr. Stanford: Stanford University Press, 1970, 78-86.

32. Wilfrid Sellars. "Some Reflections on Language Games." In In the Space of Reasons. Edited by K. Scharp, and Robert Brandom. Cambridge: Harvard University Press, 2007.

33. Wilfrid Sellars. “Truth as Correspondence.” Journal of Philosophy 59 (1962): 29-56.

34. Wilfrid Sellars. "Language, Rules and Behavior.” In John Dewey, Philosopher of Science and Freedom: A Symposium. Edited by Sidney Hook. New York: Barnes and Noble, 1949, 289-315.

35. Wilfrid Sellars. Empiricism and the Philosophy of Mind. Cambridge: Harvard University Press, 1997.

36. Wilfrid Sellars. Science and Metaphysics: Variations on Kantian Themes. London: Routledge \& Kegan Paul Ltd., 1992.

37. Wilfrid Sellars. “Theoretical Explanation.” In Philosophy of Science: The Delaware Seminar. Edited by Bernard Baumrin. New York: Interscience Publishers, 1963, vol. 2, 61-78.

38. Paul Carus. Truth on Trial: An Exposition of the Nature of Truth, Early Critics of Pragmatism. Edited by John Shook. Bristol: Thoemmes Press, 2001, vol. 3, 14.

39. Richard Rorty. Objectivity, Relativism, and Truth: Philosophical Papers. Cambridge: Cambridge University Press, 1991, vol. 1.

40. Richard Rorty. Philosophy and the Mirror of Nature. Princeton: Princeton University Press, 1979. 
41. Richard Rorty. Consequences of Pragmatism (Essays 1972-80). Minneapolis: University of Minnesota Press, 1991.

42. Cheryl Misak. Truth, Politics, Morality: Pragmatism and Deliberation. London and New York: Routledge, 2000.

43. Jeffrey Stout. “On Our Interest in Getting Things Right: Pragmatism without Narcissism.” New Pragmatists. Edited by Cheryl Misak. Oxford: Oxford University Press, 2007, 7-31.

(C) 2013 by the author; licensee MDPI, Basel, Switzerland. This article is an open access article distributed under the terms and conditions of the Creative Commons Attribution license (http://creativecommons.org/licenses/by/3.0/). 